\title{
MODERASI BERAGAMA DALAM PRAKTIK BOBAHASAAN MONGONDOW (TEKS DAN MAKNA KEARIFAN LOKAL BERBAGAI SIKAP KEBAHASAAN DAN LIRIK LAGU)
}

\author{
RELIGIOUS MODERATION IN MONGONDOW \\ LANGUAGE PRACTICE (TEXT AND MEANING OF \\ LOCAL WISDOM OF VARIOUS LINGUISTIC ATTITUDES \\ AND SONG LYRICS)
}

\author{
Abdul Karim, Nensia, AM Saifullah Aldeia, \\ St. Aflahah, Abu Muslim \\ Badan Penelitian dan Pengembangan dan Pendidikan dan Pelatihan, \\ Kementerian Agama Republik Indonesia \\ karimsejarah@gmail.com
}

DOI: $10.31291 /$ jlk.v19i1.905

Diterima: 24 Februari 2021; Direvisi: 24 Juni 2021; Diterbitkan: 30 Juni 2021

\begin{abstract}
This paper aims to reveal the aspect of religious moderation in the language wisdom of the Bolaang Mongondow tribal community in Kotamobagu. A semiotic approach is used to analyze the characteristics of Mogondow's language which is very soft and smooth, associated with the language style of the Manado Malay people with a very distinctive, communicative, and familiar accent. This study finds that the structure and nature of the language come from the local characteristics of Bolaang Mongondow which are very distinctive with the height of its meaning and the strength of the influence of the narrative. This shows that language can be an effective mediation tool for every problem in society, including religious issues. Furthermore, if there is a representation of meaning and adaptation of religious situations in the language, it has the potential to become the main element in strengthening religious moderation. The tendency to always respect, take care of each other and listen to each other in this linguistic system is also an important key to maintaining the principles of balance and moderation in religion. Another aspect is the
\end{abstract}


existence of a large wisdom umbrella in this area in the form of pogugutat, making normative identification related to moderation values can be easily explored.

Keywords: Bobahasaan, local wisdom, religious moderation, orang Mongondow

\section{ABSTRAK}

Tulisan ini bertujuan untuk mengungkap aspek moderasi beragama dalam kearifan berbahasa (bobahasaan) masyarakat suku Bolaang Mongondow di Kotamobagu. Pendekatan semiotik digunakan untuk menganalisis karakteristik bobahasaan Mogondow yang sangat lembut dan halus, dikaitkan dengan corak berbahasa orang melayu Manado dengan aksennya yang sangat khas, komunikatif, dan bikin akrab. Kajian ini menemukan bahwa struktur dan pembawaan berbahasa, berasal dari karakteristik lokal Bolaang Mongondow yang sangat khas dengan ketinggian maknanya serta kekuatan pengaruh penuturannya. Hal itu menunjukkan bahwa Bobahasaan bisa menjadi alat mediasi efektif untuk setiap persoalan di masyarakat, termasuk di dalamnya persoalan keberagamaan. Lebih lanjut, jika dilakukan representasi makna dan adaptasi situasi keberagamaan dalam Bobahasaan, maka sangat potensial menjadi unsur utama penguatan moderasi beragama. Kecenderungan untuk senantiasa menghargai, saling menjaga dan saling mendengarkan dalam sistem bobahasaan ini juga menjadi kunci penting terjaganya prinsip keseimbangan dan moderat dalam beragama. Aspek lainnya adalah adanya payung kearifan besar di daerah ini berupa pogugutat, menjadikan identifikasi normatif terkait nilai-nilai moderasi dapat dengan mudah digali.

Kata Kunci: Bobahasaan, kearifan lokal, moderasi beragama, orang Mongondow

\section{PENDAHULUAN}

Bolaang Mongondow merupakan sebuah Kabupaten di Provinsi Sulawesi Utara. Ibu kota kabupaten ini adalah Lolak, terdiri dari 15 Kecamatan. Wilayah ini memiliki kekhasan kearifan lokal yang dikenal dengan sistem pogugutat. Tradisi tersebut merupakan salah satu alat perekat sosial masyarakat yang telah tumbuh dan berkembang sejak dulu dan mengilhami pelaksanaan kehidupan sosial masyarakatnya.

Pogugutat merupakan wujud gotong royong masyarakat Bolaang Mongondow yang tertuang dalam tradisi. Pogugutat 
juga merupakan pembentuk struktur masyarakat yang sarat dengan nilai-nilai toleransi, di mana masyarakat sudah sedemikian ter-biasa untuk senantiasa saling bekerja sama, sudah menjelma menjadi kebiasaan masyarakat yang berlangsung sejak dulu.

Sistem kearifan lokal masyarakat Bolaang Mongondow mengalami perjumpaan dengan modernitas dan suasana sosial ke masyarakat terus berkembang, hal ini juga cukup berpengaruh pada akses pengembangan sumber daya manusia. ${ }^{1}$ Pada bagian kebahasaan, Masyarakat Bolaang Mongondow sebagian besar sudah tidak mengenal Bobahasaan sebagai budaya berbahasa mereka.

Di tengah pengembangan itu, masyarakat Bolaang Mongondow yang mengasosiasikan diri dengan semangat kesatuan dan identitas lokal yang sama dalam wujud kesatuan wilayah. Totabuan merupakan istilah untuk menyebut sebuah kesatuan wilayah. Totabuan kemudian memunculkan gagasan eksploratif yang mengatasnamakan solidaritas lokal untuk memunculkan ide membentuk daerah otonomi sendiri sebagai satu kesatuan administratif provinsi Bolaang Mongondow yang merangkul 5 kabupaten di sekitarnya. ${ }^{2}$

Di sisi lain, secara fungsional kearifan lokal juga banyak digaungkan sebagai marwah toleransi dalam sistem bermasyarakat dan beragama. Sehingga kearifan lokal itu berposisi sebagai narasi yang dapat membangun moderasi beragama. kemudian menjadi penanda identitas masyarakat Bolaang Mongondow itu sendiri.

Fakta ini menjadi menarik untuk dieksplorasi lebih lanjut, ketika ada semangat besar untuk bertumbuh mandiri menggunakan pendekatan penyatuan kultural sebagai salah satu basis pertumbuhannya. Pengembangan moderasi beragama kemudian menjadi objek penting dalam upaya merekatkan bangsa yang menghendaki pengelolaan masyarakat secara adil dan seimbang.

\footnotetext{
${ }^{1}$ Almunawar Bin Rusli, "Laporan Penelitian Folklore Bolaang Mongondow," 2020, 4-5.

${ }^{2}$ Jhon Rivel Purba, Sejarah Sosial Ekonomi Bolaang Mongondow 1901-1905 (Yogyakarta: Amara Books, 2019), 11-13.
} 
Usaha itu dilakukan dengan menggunakan perspektif kebudayaan dan keberagamaan yang tidak tunggal.

Pengkajian dan penggalian khusus terkait potensi kearifan lokal penting diangkat ke permukaan sebagai basis data pengejewantahan dan pengembangan wawasan kebangsaan dan keagamaan, yang (boleh jadi) jika dikembangkan lebih lanjut dapat menjadi bagian utama pengembangan moderasi beragama berbasis kearifan lokal. ${ }^{3}$ Kajian ini menjadi signifikan di tengah penguatan karakter dan wawasan kebangsaan yang dibangun dan digaungkan melalui penerapan nilai yang terkandung dalam Bobahasaan. Nilai yang terkandung dalam Bobahasaan yakni tutur kata yang sopan dan lembut.

Melalui aspek kebahasaan, moderasi beragama dapat dibangun. Bobahasaan merupakan produk budaya yang diproduksi oleh masyarakat Bolaang Mongondow. Kondisi demikian juga terjadi pada masyarakat Bugis di Sulawesi Selatan. Bentuk moderasi masyarakat Bugis dituangkan dalam paseng (petuah leluhur). Isi dari paseng adalah pesan moral kemudian dijadikan sebagai pedoman hidup masyarakat. Pesan-pesan tersebut dituangkan dalam bentuk sajak atau syair.

Bobahasaan memiliki bentuk yang sama dengan paseng, akan tetapi Bobahasaan memiliki keunikan tersendiri. Misalnya, bahasa yang digunakan sangat sastrawi, ketika mendengar lantunan dari bahasa tersebut, kita seakan terhipnotis dengan keindahan bahasa dan lantunannya. Bobahasaan tidak hanya menjadi syair saja tetapi juga digunakan untuk menengahi sebuah masalah. Selain itu, Bobahasaan juga tertuang dalam syair lagu di mana isi dari Bobahasaan sebagian besar berisi pesan moderasi beragama.

Hal inilah yang diharapkan dapat menjadi instrumen moderasi, khususnya dalam pengembangan dan pengamalan ajaran agama yang lebih toleran. ${ }^{4}$ Di dalamnya memuat petuah kesetia-

${ }^{3}$ Irwan Abdullah, Agama dan Kearifan Lokal dalam Tantangan Global (Yogyakarta: Sekolah Pascasarjana UGM dan Pustaka Pelajar, 2008), 34.

${ }^{4}$ Muhammad Adlin Sila, "Sila, Adlin. 2011. Peta Penelitian Budaya di Lingkungan Badan Litbang dan Diklat Kementerian Agama RI," Harmoni (Jurnal Multikultural dan Multireligius) X, no. 4 (2011): 764-82. 
kawanan sosial berbasis agama agar terhindar dari konflik atas nama agama. Kearifan lokal yang muncul di Nusantara dan memiliki kekhasan di setiap daerah selalu menonjolkan komunitas atau kebersamaan di dalam makna dan pelaksanaannya. ${ }^{5}$

Moderasi beragama yang berujung kerukunan adalah fondasi bangsa Indonesia. Tanpa kesediaan untuk hidup rukun, masyarakat Indonesia akan mengalami fase disintegrasi. Hal ini dapat terjadi karena Indonesia adalah bangsa yang tersusun dari beraneka ragam identitas sosial, agama, dan budaya. Selanjutnya, pengamatan terhadap kearifan lokal masyarakat menjadi salah satu pintu masuk melacak orientasi moderasi berbasis budaya, karena di dalamnya memuat secara komprehensif tentang memori kolektif masyarakat atas kebudayaan dan kebijaksanaan hidup yang telah berlangsung turun temurun. ${ }^{6}$

Semua faktor itulah yang menjadi fokus kajian dalam rangka melihat dan menemukan unsur-unsur moderasi yang terwariskan dan terkoneksi dalam kehidupan sehari-hari masyarakat. Untuk menghindari kepunahan khazanah keagamaan sebagai reproduksi pengetahuan dan identitas maka lokalitas perlu diabadikan. Jalan yang dapat ditempuh yakni dengan melakukan penelitian, pendokumentasian, pencatatan dan masih banyak lagi.

Bobahasaan tertuang dalam lagu daerah Mongondow. Salah satu liriknya berbunyi Yo napakaingkita noposikon agama Mobiag tumonpia moalus in dodia Moluko im Bahasa kon tumpala intau Mobiag kombonuin dunia (Walau kita berbeda agama, bertingkahlah yang baik dan halus pembawaan, berbahasa yang lembut kepada sesama manusia yang hidup di dunia). ${ }^{7}$ Potongan lirik tersebut menggambarkan bagaimana seharusnya orang Bolaang Mongondow bersikap.

${ }^{5}$ Mashudi, "Pendidikan Keberagaman Sebagai Basis Kearifan Lokal (Gagasan Kerukunan Umat Beragama)," Jurnal Tarbawi 2, no. 1 (2014): 4766.

${ }^{6} \mathrm{Abu}$ Muslim, "Kitorang Samua Basudara: Bijak Bestari di Bilik Harmoni," Jurnal Harmoni, Puslitbang Kehidupan Keagamaan Badan Litbang dan Diklat Kementerian Agama Republik Indonesia 15, no. 2 (2016): 109-22.

${ }^{7}$ Wawancara Sumitro Tegela, 21 Februari 2020 
Aspek moderasi beragama terbaca dalam teks tersebut. Teks menjadi penanda yang kemudian menjadi kekuatan yang membawa pengaruh ketika teks itu dimaknai. Orang Bolaang Mongondow harus bersikap toleran kepada masyarakat yang berbeda agama agar tercipta kondisi yang aman, tenteram dan jauh dari konflik. Dengan adanya teks tersebut maka tidak akan membentuk pribadi yang moderat dan jauh dari sikap radikal.

Berdasarkan uraian di atas, maka penelitian tentang moderasi dari sudut pandang kebahasaan sangat penting untuk dilakukan. Masalah pokok yang diajukan adalah bagaimana sistem kebahasaan yang dimiliki oleh masyarakat dapat memperkuat moderasi beragama? Pertanyaan tersebut dapat dirinci terkait bagaimana praktik kebahasaan masyarakat Bolaang Mongondow yang memiliki fungsi mencipta Moderasi? Bagaimana internalisasi nilai moderasi beragama tercerminkan dalam lagu-lagu daerah dan praktik kebahasaan lainnya? Dan, bagaimana sikap kebahasaan ketika diperhadapkan pada kelompok masyarakat yang berbeda agama dan budayanya?

Penelitian ini difokuskan pada penelusuran terkait kearifan lokal masyarakat yang menjadi elemen penting penciptaan iklim moderasi beragama. Tentu saja hal ini diawali dengan melakukan identifikasi kearifan lokal yang ada dan berkembang di masyarakat secara fungsional untuk selanjutnya menghubungkannya dengan penciptaan moderasi beragama yang dijiwai dari kearifan lokal itu di masyarakat.

Moderasi beragama merupakan keseimbangan antara sikap dan pengamalan beragama (inklusif) disertai penghormatan atas pelaksanaan keberagamaan orang lain yang keyakinannya berbeda (eksklusif). ${ }^{8}$ Selain itu, moderasi beragama juga bermakna melaksanakan perintah agama dengan membentuk individu yang taat secara personal dan menjadikan pengetahuan agama itu sendiri sebagai instrumen dalam menghargai umat lain.

Moderasi agama adalah konsep pembentukan kehidupan yang tentram dan seimbang antarumat beragama yang heterogen dalam satu kesatuan NKRI. Dikursus moderasi selanjutnya

${ }^{8}$ Kementerian Agama, Moderasi beragama. (Badan Litbang dan Diklat, Departemen Agama RI, 2019), 18. 
sering dijabarkan melalui 3 (tiga) pilar yakni: pertama, moderasi pemi-kiran (kemampuan memadukan antara teks dan konteks). Kedua, moderasi gerakan (bahwa penyebaran agama yang bertujuan mengajak kebaikan dan menjauhkan kemungkaran senantiasa didasarkan pada dakwah dengan cara-cara yang baik). Ketiga, moderasi perbuatan (penguatan relasi antara keberagamaan dengan tradisi kebudayaan masyarakat lokal yang saling terbuka dan membangun dialog dalam rangka membangun kebudayaan baru. ${ }^{9}$

Di Indonesia Timur, terdapat banyak sekali sistem kultural yang digunakan sebagai salah satu pendekatan utama dalam rangka membangun harmoni. Sistem itu kemudian diejawantahkan dalam institusi lokal yang mendukung kerukunan seperti sipakatau sipakalabbi di Sulawesi Selatan, institusi pela gandong, kapata, jugulu-jugulu, pantong, ale rasa beta rasa torang samua basudara di Maluku, dapo moa-moa sioho, dapo angka angkatau, dapo mo moologho, dapo adha adhati, dan dapo pia piaral dapo bhini-bhini kuli di Muna Sulawesi Tenggara, serta banyak lagi nilai yang bisa digali lebih mendalam dan dikedepankan sebagai alat rukun. Kesemuanya diartikulasikan dalam setiap tata budaya dan tata kelola masyarakat yang di dalamnya dapat mengajak orang untuk berdamai. ${ }^{10}$

Misalnya sipakatau sipakalabbi artinya saling memanusiakan. Pemaknaan terhadap frasa ini memberikan arti bahwa kita harus memperlakukan manusia dengan manusiawi. Berbuat baik dengan sesama dan tidak saling menyakiti satu sama lain. Penciptaan makna terhadap frasa tersebut sangat luas dan menyentuh banyak aspek dalam masyarakat.

Penelitian terbaru adalah penelitian moderasi beragama yang digali melalui tradisi lisan masyarakat yang dilakukan oleh Balai Litbang Agama Makasar tahun 2019 dengan menyasar empat tradisi lisan yakni Tradisi Lisan Iko-Iko Siala Tangang Masyarakat Suku Bajau, Pasawari tradisi lisan anak negeri Maluku, Tradisi Akbaruga masyarakat Gantarangkeke di

\footnotetext{
${ }^{9}$ Rumadi Ahmad, "Penguatan Moderasi Beragama," Kompas, 2019.

${ }^{10}$ Sabara, "Indeks Kerukunan Umat Beragama di Kabupaten Muna" (Makassar, 2014), 5-6.
} 
Bantaeng, serta Tradisi Lisan Tarsul masyarakat Kutai Kartanegara. ${ }^{11}$

Bobahasaan juga merupakan tradisi lisan masyarakat Bolaang Mongondow yang tertuang dalam lagu-lagu daerah. Berbeda dengan penelitian sebelumnya, Bobahasaan cukup kontradiktif dengan kondisi kebahasaan masyarakat setempat. Bahasa sahari-hari mereka terkesan tegas namun Bobahasaan terkesan lembut dan perlu pemaknaan mendalam.

Penelitian ini didasarkan pada aspek keseimbangan dalam lembaga sosial masyarakat. Kegiatan manusia terpola berdasarkan norma-norma yang dipahami oleh masyarakat. Norma tersebut menjadi konsensus yang mengikat masyarakat dalam menjalankan kehidupannya. Di dalam masyarakat terdapat pula lembaga yang mengikat masyarakat secara kolektif. Lembaga tersebut kemudian memengaruhi sistem sosial. Akhirnya akan meng-ubah kondisi sistem secara kolektif. Di dalam sistem kemasyarakatan itu sendiri memiliki unsur tertentu yang kemudian mengalami perubahan sehingga memengaruhi unsur lainnya secara menyeluruh. $^{12}$

Keseimbangan menjadi poin utama dalam penyatuan berbagai elemen yang saling mengikat satu sama lain. ${ }^{13}$ Struktur masyarakat tidak terlepas dari kebutuhan yang beragam membuat setiap masyarakat saling membutuhkan satu sama lain. ${ }^{14}$ Dalam penelitian ini analisis fungsional dibutuhkan untuk melihat seberapa besar fungsi tradisi lisan dalam membentuk pola masyarakat untuk mengamalkan moderasi agama dan seberapa jauh teks yang terlisankan membentuk pola perilaku.

${ }^{11}$ Abu Muslim, Idham, dan Muhammad Subair, "Iko-Iko Siala Tangang (Tracing Moderatism of Religious Concept From the Oral Traditions of Bajau)," in Proceedings of the First International Conference on Religion and Education 2019, October 8-12 2019, ed. oleh Dkk Basri (Bintaro: European Union Digital Library (EAI), 2019), https://doi.org/http://dx.doi.org/ 10.4108/ eai.8-10-2019.2294520.

${ }^{12}$ Thomas F O’dea, Sosiologi Agama Suatu Pengenalan Awal (Terj.) (Jakarta: CV. Rajawali, 1985), 78.

${ }^{13}$ George Ritzer, Sosiologi Ilmu Pengetahuan Berparadigma Ganda (Jakarta: Rajawali Press, 1992), 25.

${ }^{14}$ Wiliam J Goode, Sosiologi keluarga (Jakarta: Bumi Aksara, 1995), 3. 
Ketika sebuah karya puisi (sastra) mengandung makna tersirat maka akan terjadi beberapa kondisi yakni pergantian makna (displacing of meaning), penyimpangan makna (distorsing of meaning) dan penciptaan makna (creating of meaning). Displacing terjadi ketika ada bagian metaphor dan mentonymy. Distorsing terjadi ketika ada bagian yang ambigu, kontradiktif, dan tidak bermakna dan creating of meaning terjadi ketika ruang berposisi sebagai ketika ruang tekstual berfungsi sebagai prinsip organisasi untuk membuat tanda-tanda dari item linguistik yang mungkin tidak bermakna sebaliknya. ${ }^{15}$

Bobahasaan sebagai sistem kebahasaan memiliki karakter dengan kondisi pemaknaan yang digagas oleh Michael Camille Riffaterre. Bobahasaan tertuang dalam syair lagu yang dilantunkan oleh masyarakat Bolaang Mongondow. Bahasa itu hanya digunakan dalam kasus tertentu, misalnya saat menengahi sebuah masalah. Bahasa yang digunakan sangat berbeda dengan penggunaan bahasa umum. Perbedaannya terletak pada cara berbahasanya yakni Bobahasaan memiliki makna mendalam dan sangat lembut sedangkan bahasa umum orang Mongondow terkesan lebih tegas.

Praktik penggunaan Bobahasaan merupakan salah satu bagian yang ingin disorot oleh artikel ini. dalam praktik tersebut artikel ini menarik aspek moderasi beragama yang disampaikan melalui teks dari bobahasaan tersebut. Konsep intertekstual digunakan untuk menarik makna melalui interpretasi syair Bobahasaan yang tertuang dalam lagu.

Menurut Stewart ${ }^{16}$ budaya yang berbeda dan tradisi yang majemuk adalah dua hal yang penting diperhatikan dalam melakukan pembahasan tentang religiositas masyarakat, di mana di dalamnya persoalan mistik, Islam, dan lokalitas akan mengalami hibriditas dalam melihat hubungan antara religi dan ritual itu sendiri. ${ }^{17}$ Apabila dalam warna-warni adat, pluralitas dan

15 Michael. Riffaterre, Semiotics of Poetry (Bloomington [Ind.]: Indiana University Press, 1984), 2.

${ }^{16}$ Andrew Beatty, Varieties of Javanese Religion: An Anthropological Account (Cambridge: Cambridge University Press, 2004), 4.

${ }^{17}$ Ruth Finnegan, Oral Traditions and The Verbal Arts: A Guide to Research Practices (London: Routledge, 1997). 
keberagaman budaya terdapat sinkretisme, maka yang terjadi adalah sebuah proses dinamik dan berulang. ${ }^{18}$ Tegasnya, bahwa kajian budaya-religi dapat diarahkan untuk memahami bahwa religi tidak melulu tentang agama, tetapi merupakan fenomena kultural. Religi merupakan representasi budaya sebuah bangsa yang unik. ${ }^{19}$

Religi adalah dasar keyakinan, sementara aspek kultural adalah bagian yang mengitarinya. Sehingga dapat dikatakan bahwa religi adalah fenomena budaya yang universal. Religi adalah budaya itu sendiri dengan kekhasannya. Meskipun dalam praktik dan penerapannya, keduanya sering berbeda, namun memiliki titik jumpa yang menarik.

Menurut Geertz, ${ }^{21}$ religi adalah sebuah pengalaman unik yang bernilai, memuat identitas diri, dan kekuatan khusus. Pada dasarnya agama dapat diimplementasikan sebagai alat perekat kohesi sosial. Agar agama dapat fungsional menjadi alat pemersatu hubungan sosial ada sejumlah poin yang seyogyanya mendapat atensi masyarakat ${ }^{22}$ antara lain; menghilangkan ego sektoral (kelompok), moderat dan saling bertoleransi, dan juga melahirkan pemahaman bersama akan unity in diversity. ${ }^{23}$

Kajian ini menggunakan pendekatan kualitatif dalam rangka menelusuri kearifan lokal dalam masyarakat yang berperan dalam menciptakan moderasi beragama. Penelitian memilih

${ }^{18}$ Dipodjojo Asdi, Folklore dan Pendidikan: Dalam Publikasi Ilmu Keguruan Sastra Seni, 1 ed. (Yogyakarta: FKSS IKIP, 1970).

${ }^{19}$ P.J. Zoetmulder, "'The Significance of the Study of Culture and Religion for Indonesian Historiography," in An Introduction to Indonesian Historiography, ed. oleh Soedjatmoko. (Jakarta: PT Equinox Publishing Indonesia, 2007).

${ }^{20}$ Bikhu Parekh, Rethinking Multiculturalism: Cultural Diversity and Political Theory (London: Macmilan, 2000).

${ }^{21}$ Clifford Geertz, "Religion as Cultural System” Local Knowledge: Futher Essays in Interprtative Anthropology (New York: Basic Book, 1983), 170.

${ }^{22}$ Mashudi, "Pendidikan Keberagaman Sebagai Basis Kearifan Lokal (Gagasan Kerukunan Umat Beragama)," 52.

${ }^{23}$ Yunus Rahawarin, "Kerjasama Antarumat Beragama dalam Menyelesaikan Konflik di Kota Ambon dan Kota Tual Maluku” (UIN Sunan Kalijaga Yogyakarta, 2012). 
Suku Bolaang Mongondow sebagai objek kajian, yang terletak di Kotamobagu Provinsi Sulawesi Utara. Dalam penelitian ini, informan kunci adalah unsur pemerintah, agamawan, dan tokoh masyarakat (sesepuh, pelaksana tradisi, pewaris). Informan ahli adalah akademisi, antropolog, sosiolog, peneliti lokal, dan para pakar sosial-keagamaan. Informan biasa adalah masyarakat umum. Observasi dan wawancara digunakan sebagai media pengumpulan data. ${ }^{24}$ Meskipun sesungguhnya, peneliti sendirilah yang menjadi instrumen utamanya. ${ }^{25}$ Sehingga analisis data dapat dilakukan dalam proses penelitian, analisis dilakukan secara interaktif dan berkesinambungan. ${ }^{26}$ Secara teknis, analisis isi (Content Analysis) digunakan dalam mengkaji kandungan moderasi beragama yang digali dari isi Bobahasaan sebagai kearifan lokal masyarakat Bolaang Mongondow. Selanjutnya analisis fungsional digunakan untuk melihat seberapa berfungsi kearifan lokal itu memolakan masyarakatnya untuk mengamalkan moderasi agama, dan terakhir, analisis kebijakan digunakan untuk perumusan rekomendasi kebijakan. ${ }^{27}$

\section{HASIL DAN PEMBAHASAN}

\section{Sekilas tentang Bolaang Mongondow}

Keturunan Tumotoibokol-Tumotoboikat, dan keturunan Gumalangit-Tendeduata disebut-sebut sebagai asal muasal Suku Mongondow. Mereka bermukim di daerah gunung Komasaan Bintauna. Grup keturunan inilah kemudian yang pada abad 8 dan 9 beranak-pinak dan menyebar ke berbagai daerah di Tudu in Lobagin, Ginolantungan, Pondoli, Buntalo. Lalu melanjutkan penyebarannya ke daerah pedalaman Tudi in Lolayan, Tudu in

${ }^{24}$ Jhon W Cresswell, Research Design, Qualitative and Quantitative Approaches (California: Thousand Oaks, 1994).

${ }^{25}$ Sugiyono, Metode Penelitian Pendidikan dan Pendekatan Kuantitatif, Kualitatif, dan R\&D (Bandung: Alfabeta, 2010), 305.

${ }^{26}$ MA. Milles, M.B. and Huberman, Qualitative Data Analysis. London: Sage Publication. (London: Sage Publication, 1994).

${ }^{27}$ Walter J. Ong, Orality and Literacy: The Technologizing of the Word Diterjemahkan Oleh Iffati, Rika. Kelisanan dan Keaksaraan (London and New York: Routledge, 2013). 
Bumbungon, Mahag, Tudi in Sia, Tudu in Passi, Siniow dan sekitarnya. Kehidupan yang dijalani dilalui dengan sistem mata pencaharian berburu dan berpindah-pindah, mengolah ragam tanaman umbi-umbian, serta memaksimalkan area laut dengan menangkap ikan. Perkembangan selanjutnya kelompok masyarakat yang tergabung dalam beberapa elemen Suku Mongondow inilah yang kemudian membentuk aliansi Kerajaan Bolaang, yang dalam perjalanannya kemudian dikenal dengan Bolaang Mongondow. ${ }^{28}$

Proses perjalanan yang berpindah-pindah itu dalam perkembangannya kemudian membangun sistem bercocok tanam, berkebun, dan berburu hewan, di mana kelompok penduduk yang memilih nomad sampai ke pedalaman Bolaang Mongondow, selalu mencermati lokus yang terang dan tembus cahaya matahari yang dikenal dengan istilah 'golaang', selain itu mereka juga mengembangkan sistem pengasapan dan pengeringan sebagai usaha mengawetkan hasil buruan menggunakan api yang dikenal dengan istilah "totaboyan". Selanjutnya, ketika mereka atau sebagian dari mereka kemudian memilih berpindah tempat, dari istilah lokal totaboyan inilah, kemudian menjelma dengan istilah "Totabuan" yang berarti "Tempat Pemukiman Baru". 29

Penyelenggaraan administrasi pemerintahan. Dulu ada namanya Afdeeling Bolaang Mongondou, Zelfbestuur Bolaang Mongondou, dan Het Rijk Bolaang Mongondou. Sejak 1850 nama Bolaang Mongondow dijadikan nama resmi dalam konstruksi pemerintahan kolonial baru beriringan dengan diberlakukan RR 1854 atau konstitusi Hindia Belanda. Sebelumnya Bolaang dan Mongondow masih merupakan wilayah yang terpisah. Ketiga, dipakai sebagai nama identitas etnik atau nama dari salah satu suku bangsa Indonesia. Keempat, Bolaang Mongondow dipakai menjadi sebutan untuk bahasa dominan di

${ }^{28}$ Lily E.N. Saud, Budaya Masyarakat Suku Bangsa Bolaang Mongondow di Sulawesi Utara, Proyek Pem (Manado: Kementerian Kebudayaan dan Pariwisata Deputi Bidang Pelestarian dan Pengembangan Budaya Balai Kajian Sejarah dan Nilai Tradisional Manado, 2004).

${ }^{29}$ Purba, Sejarah Sosial Ekonomi Bolaang Mongondow 1901-1905, 5. 
kawasan distrik awal yaitu Mongondow, Dumoga, Kotabunan dan Bolaang. ${ }^{30}$

Tahun 1958, Kerajaan Mongondow kemudian bergabung ke dalam Negara Kesatuan Republik Indonesia menjadi Kabupaten Bolaang Mongondow, dalam wilayah administratif provinsi Sulawesi Utara. Pada fase itu, 95\% masyarakat suku Mongondow memeluk agama Islam, dan sisanya tersebar dalam agama Hindu, Kristen, dan Katolik. Sebelumnya, pihak Kerajaan Bolaang Mongondow banyak melakukan interaksi dengan VOC, serta juga pernah menjadi bagian wilayah jajahan Belanda, sebagaimana kerajaan umumnya di Indonesia. ${ }^{3}$

Interaksi itu kemudian memberikan dampak pengenalan bahan dagangan dari Eropa, sekaligus sebagai pintu masuk pengenalan ajaran agama Kristen. Selanjutnya sekolah-sekolah Kristen didirikan oleh Pemerintah Kolonial Belanda dan mengirim pendeta di tanah Totabuan. Pada proses inilah, yang selanjutnya memengaruhi proses perubahan sosial suku Mongondow. Hal ini sekaligus membuat karakteristik keberagamaan orang-orang Bolaang Mongondow menjadi cukup berwarna dan potensial menjalankan pola hubungan antarmasyarakat yang berasal dari agama yang berbeda. ${ }^{32}$

Pengalaman masyarakat Bolaang Mongondow tetaplah merupakan bagian dari pengalaman manusia universal sebagaimana pengalaman masyarakat-masyarakat lain. Di beberapa wilayah yang tersebar di Bolaang Mongondow, mulai dari kawasan pesisir hingga pegunungan, terdapat banyak desa-desa di mana masyarakatnya terus bekerja keras untuk meningkatkan taraf hidup mereka, kerabat mereka, orang-orang yang mereka kasihi serta keturunan mereka. ${ }^{33}$ Bekal pengalaman Panjang

${ }^{30}$ Rusli, "Laporan Penelitian Folklore Bolaang Mongondow," 4.

${ }^{31}$ Hasanuddin, Kerajaan Bolango: Dari Tapa Ke Bolaang Uki (Suatu Tinjauan Sejarah Sosial) (Yogyakarta: Amara Books., 2013).

${ }^{32}$ Steven Sumolang dan Janeke Peggy, Pemetaan Konflik Sosial pada Masyarakat Dumoga di Kabupaten Bolaang Mongondow (Yogyakarta: Amara Books, 2018).

${ }^{33}$ Muhammad As'ad, "Agama dalam Dimensi Sosial dan Budaya Lokal: Studi tentang Upacara Siklus Hidup Masyarakat Bolaang Mongondow," Al-Qalam 10, no. 2 (2018): 55, https://doi.org/10.31969/alq.v10i2.600. 
inilah yang potensial dijadikan sebagai pintu masuk mengakses nilai-nilai kearifan lokal yang dimiliki sejak lama untuk diejawantah sebagai basis kultural pengembangan moderasi beragama berbasis kearifan lokal.

\section{Potensi Kearifan Lokal Suku Bolaang Mongondow: Mototompiaan, Mototobian, bo Mototanoban}

Sistem kearifan lokal ini pada dasarnya adalah sikap yang mengilhami sanubari terdalam masyarakat Bolaang Mongondow. Bahkan kini, kearifan lokal ini menjadi semboyan yang bisa dijumpai di gerbang batas wilayah Kota Mobagu sebagai hukum adat yang dihormati yang tercermin dalam Mototompiaan, Mototabian Bo Mototanoban (saling peduli, saling menyayangi, saling merindukan). Praktik ini lah yang menjadi aspek pemersatu masyarakat sebagai bagian yang tidak terpisahkan dengan falsafah persaudaraan lainnya yang tersebar di Sulawesi Utara, sebut saja misalnya Si Tou Timou Tou (seorang menjadi paripurna ketika dia bermanfaat bagi orang lain) dari Minahasa. ${ }^{34}$ Selain itu juga ada istilah Mobobangkalan, bo Moboaheran (saling menakjubi dan saling menghormati) di mana dalam setiap kelompok masyarakat, kearifan ini sangat mengikat yang kemudian dikenal dengan istilah "mopokoropot bo mopokoringan kon Bolaang Mongondow" (memperkuat dan mempersatukan masyarakat Bolang Mongondow). ${ }^{35}$

Bahkan kini, Mototompiaan, Mototabian Bo Mototanoban telah dapat dikatakan sebagai benteng pemersatu. ${ }^{36}$ Mototompiaan, secara aktual dimaknakan sebagai bentuk saling peduli satu sama lain dan turut bertanggung jawab bersama mewujudkan pembangunan daerah. Kata dasarnya adalah Tompia (memperbaiki). Di mana imbuhan me-an kemudian bermakna saling memperbaiki. ${ }^{37}$

${ }^{34}$ Abu Muslim et al., "Merawat Kerukunan Umat Beragama Berbasis Kearifan Lokal di Kawasan Timur Indonesia" (Makassar, 2016).

${ }^{35}$ Balai Pelestarian Nilai Budaya (BPNB) Manado, Upacara Monibi di Bolaang Mongondow (Yogyakarta: Kepel Press, 2015).

${ }^{36}$ Lily E.N. Saud.

${ }^{37}$ As'ad, "Agama dalam Dimensi Sosial dan Budaya Lokal: Studi tentang Upacara Siklus Hidup Masyarakat Bolaang Mongondow.” 
Mototabian, berasal dari kata Tabi (cinta-kasih sayang), sehingga mototabian dapat bermakna saling menyayangi, dengan kata lain ada aspek kasih sayang antara kemahakuasaan Tuhan dengan kasih sayang sesama manusia. ${ }^{38}$ Lebih lanjut, pemaknaan saling menyayangi adalah merupakan wujud senasib sepenanggungan yang senantiasa berada dalam rahmat Tuhan.

Mototanoban, berasal dari kata Tanob (kenang-rindu), yang dapat diterjemahkan dalam wujud saling mengenang dan saling merindukan satu sama lain, sehingga kapan dan di mana pun berada, orang-orang Bolaang Mongondow senantiasa saling meridnukan dan mengenang satu sama lain. ini berarti bahwa dalam aspek yang lebih khusus, setiap masyarakat berada dalam suasana batin yang terikat. Jika kita senantiasa saling mengenang, maka dengan sendirinya dapat saling mengingat yang secara otomatis juga melahirkan kebaikan-kebaikan bersama. ${ }^{39}$

Dengan demikian mototompiaan, mototabian, dan mototanoban merupakan rangkaian falsafah sikap mental yang utuh, baik lahiriah maupun batiniah. Maka dari itu, konsep lokal ini memiliki potensi untuk menjadi kearifan lokal karena dengan kepedulian, cinta dan kasih sayang, serta perasaan yang saling merindukan adalah bagian penting dari menciptakan iklim kebersamaan dan harmoni masyarakat. Meskipun terkesan normatif, akan tetapi karena ini sudah berlangsung turun temurun, maka konsep ini telah menjadi ingatan kolektif masyarakat yang pada akhirnya dapat membentuk karakter kebersamaan satu sama lain.

\section{Praktik Kebahasaan dalam Bentuk Sikap Kebahasaan dan Lirik Lagu}

Bobahasaan adalah sistem berbahasa orang Mongondow yang merupakan karakteristik Bahasa Mongondow dengan lapisan makna yang sangat dalam. Bobahasaan awalnya digunakan oleh masyarakat adat dalam memediasi persoalan yang terjadi di masyarakat, dengan menggunakan dan memilih bahasa tutur yang sangat halus dan lembut, serta memiliki makna yang sangat kuat.

\footnotetext{
${ }^{38}$ Steven Sumolang dan Janeke Peggy.

${ }^{39}$ Rusli, "Laporan Penelitian Folklore Bolaang Mongondow."
} 
Posisi Bobahasaan ini sebagai sistem tuturan masyarakat yang seluruhnya menggunakan bahasa Mongondow asli yang tidak lebih banyak menggunakan bahasa kiasan dengan lapisan makna yang sangat tinggi, atau dalam konteks bahasa yang sangat tinggi. Bobahasaan ini sangat efektif untuk meredam dan memediasi konflik yang terjadi, karena pesannya mampu menyentuh sanubari terdalam orang yang mendengarkannya. Sebagai contoh: "Ketika terjadi persoalan pembangunan gereja di Kotamobagu, penyelesaiannya dilakukan dengan mendekati orang-orang yang melakukan konfrontit terhadap gereja itu dengan tutur Bahasa yang sangat halus yakni dalam Bahasa Bolaang Mongondow (Bobahasaan). Padahal sebelumnya sudah dilakukan mediasi dengan Bahasa Indonesia tetapi mereka tetap bersikeras menolak pembangunan gereja itu. Namun setelah didekati dengan Bobahasaan, mereka akhirnya luluh." (Wawancara dengan Kiyai Syahran, Ketua BKSAUA Kotamobagu, tanggal 20 Februari 2020).

Belakangan, sistem Bobahasaan ini berkembang dan beradaptasi dengan bahasa Melayu Manado sebagai bahasa seharihari. Lebih lanjut, penulis kemudian akan melakukan pendalaman khusus terhadap kearifan lokal ini, di mana pengembangan kerukunan hidup dan moderasi beragama sangat jarang dilihat melalui pendekatan bahasa, namun pada prinsipnya sangat potensial sebagai alat perekat sosial.

Pengembangan pemerhatian atas kearifan lokal yang di dalamnya dapat digali nilai-nilai moderasi beragama pada prinsipnya telah terstruktur dalam Bobahasaan sehari-hari orang Mongondow. Pada aspek inilah muatan nilai-nilai kebaikan, keadilan, serta prinsip mengayomi akan dapat jelas terlihat dalam tindak tutur orang mongondow. Karakteristik ini melekat dalam kearifan lokalnya untuk senantiasa Moluko' In Bahasa, Moalus in dodia (Berbahasa yang lembut dan bertingkah laku halus).

Pengejewantahan atas Bobahasaan lembut itu dapat dilihat misalnya dalam kehidupan sehari-hari orang Mongondow yang senantiasa bersosialisasi dan berargumentasi dengan cara-cara yang santun. Bagi orang Mongondow karakteristik ini sudah tertanam dalam hati sebagai pesan leluhur untuk dilaksanakan. Teramat penting untuk dicamkan dalam hati karena dengan 
begitu, kebahagiaan di dalam penghidupan akan mudah diraih. Tentu jika kesadaran berbasis pesan luhur ini digalakkan, maka segala bentuk penyelesaian masalah-masalah kehidupan dapat dicarikan jalan keluarnya. Beberapa tuntunan keramahan, kehalusan dan kesantunan Bahasa tersebut terlihat jelas dalam pesan-pesan yang dituangkan dalam lirik lagu-lagu daerah orang Mongondow.

\section{Tabel 1.}

Lagu Daerah Mongondow

\begin{tabular}{ll}
\hline \hline \multicolumn{1}{c}{ Transliterasi } & \multicolumn{1}{c}{ Terjemahan } \\
\hline Nonomon Kon Dodob & Camkan dalam Hati \\
Nonomon kom bonuin dodon & Camkanlah di dalam hati pesan \\
& leluhur \\
Koyow on mogoguyang simba' & Agar mendapat kebahagiaan di \\
motompia ing kohaya'an & dalam penghidupan \\
Kom bonuing kobiagan & Saling memberi kebaikan, \\
Mototompiaan Bo mototabian Bo & berkasih-kasihan \\
Mototanoban doman & Dan saling mengenang sahabat \\
Mosamben tumpala intau & semua insan \\
Yo indongogan bi'in tongginaing & Dan dengarkan juga semua nasihat \\
guyanga minta, & orang tua \\
Tumolutuikan dodudui, & Hidup jujur dan setia jalankan \\
Kontopotundu' in agama, & ajaran agama \\
Moluko' In Bahasa, Moalus in dodia & Berbahasa lembut, bertingkah \\
& laku halus \\
Tonggolipu in dika koliongan, & Gotong Royong janganlah \\
Bo pogugutat in pobaya'an, & dilupakan \\
Monompia kon Totabuan, Tagu'an & Dan membangun kampung \\
kon adi' boampu, & halaman \\
Sim Bayongandon nato komintan in & Warisan anak cucu kita \\
mogutatbi'motolu adi & Karena kita sekalian ini \\
& Adalah sanak dan bersaudara \\
\hline \hline
\end{tabular}

Sumber: Wawancara Sumitro Tegela, 21 Februari 2020

Lirik lagu berjudul Nonomon Kon Dodob mengandung beberapa pesan bijak untuk menjalani kehidupan sehari-hari. Penggalan lirik Nonomon kom bonuin dodon Koyow on mogoguyang simba' motompia ing kohaya'an (camkanlah di dalam hati pesan leluhur agar mendapat kebahagiaan di dalam peng- 
hidupan) dan Mosamben tumpala intau Yo indongogan bi'in tongginaing guyanga minta (dan dengarkan juga semua nasehat orang tua). mengandung pesan tentang bakti kepada orang tua. Di penggalan lirik yang lain tersirat pesan tentang kehidupan beragama berbalut keanggunan. Pesan ini disampaikan melalui penggalan lirik Tumolutuikan dodudui, Kontopotundu' in agama, Moluko' In Bahasa, Moalus in dodia (hidup jujur dan setia jalankan ajaran agama berbahasa lembut, bertingkah laku halus). Dalam lagu tersebut juga disampaikan pesan tentang pentingnya menjaga persaudaraan yang dieksperesikan melalui penggalan lirik Kom bonuing kobiagan Mototompiaan Bo mototabian Bo Mototanoban doman (Saling memberi kebaikan, berkasih-kasihan Dan saling mengenang sahabat semua insan) dan Tonggolipu in dika koliongan, Bo pogugutat in pobaya'an, Monompia kon Totabuan, Tagu'an kon adi' boampu (Gotong Royong janganlah dilupakan Dan membangun kampung halaman Warisan anak cucu kita.

Makna yang didapat dari setiap penggalan lirik teresbut merupakan hasil dari pembacaan secara hermeneutik yang merupakan sistem pembacaan ulang dengan memberikan konvensi sastranya. Karena dalam setiap lirik lagu yang diciptakan selain ingin menyampaikan pesan juga memperhatikan aspek-aspek keindahan sastrawi agar bisa dinikmati. oleh karenanya untuk menemukan makna setiap penggalan lirik pada lagu nonomon kon dodob perlu adanya proses penciptaan arti yang baru (creating of meaning) agar bisa menangkap pesan pada lagu tersebut. Seperti halnya pada lirik Mosamben tumpala intau Yo indongogan bi'in tongginaing guyanga minta. Lirik tersebut secara eksplisit memberi pesan untuk mendengarkan nasehat kedua orang tua. Jika ditelisik lebih dalam pesan yang ada dalam lirik tersebut adalah tentang berbakti kepada orang tua dan mendengarkan nasehat adalah salah satu dari bagian kecil bentuk bakti seseorang kepada orang tuanya. 


\section{Tabel 2.}

Lagu Daerah Mongondow

\begin{tabular}{|c|c|}
\hline Transliterasi & Terjemahan \\
\hline Mogutat Motoluadi' & (Saling) Bersaudara \\
\hline $\begin{array}{l}\text { Koli gaidoing kita mogutad and } \\
\text { moguhang }\end{array}$ & $\begin{array}{l}\text { Marilah semua yang muda bahkan } \\
\text { yang tua }\end{array}$ \\
\hline $\begin{array}{l}\text { Mopolinbatu inggina tobatu cim } \\
\text { pikiran }\end{array}$ & $\begin{array}{l}\text { Membulatkan hati serta } \\
\text { menyatukan pikiran }\end{array}$ \\
\hline A mapoyosingong a mopoyotantan & $\begin{array}{l}\text { Akan membicarakan dan } \\
\text { mempertimbangkan }\end{array}$ \\
\hline Kon anai mobali'ko piaan & Apa yang menjadi kebaikan \\
\hline $\begin{array}{l}\text { Yo napakaingkita noposikon agama } \\
\text { Mobiag tumonpia moalus in dodia }\end{array}$ & $\begin{array}{l}\text { Walaupun kita beda agama, } \\
\text { bertingkalah yang baik }\end{array}$ \\
\hline $\begin{array}{l}\text { Moluko im Bahasa kon tumpala } \\
\text { intau }\end{array}$ & $\begin{array}{l}\text { Dan halus pembawaan, berbahasa } \\
\text { yang lembut }\end{array}$ \\
\hline Mobiag kombonuin dunia & $\begin{array}{l}\text { Kepada sesama manusia yang } \\
\text { hidup di dunia }\end{array}$ \\
\hline $\begin{array}{l}\text { Dikabi' mogoguregan Bo dikabi' } \\
\text { mososingkulean }\end{array}$ & $\begin{array}{l}\text { Janganlah saling mendengki dan } \\
\text { Janganlah saling membenci }\end{array}$ \\
\hline $\begin{array}{l}\text { Sing kita komintan in notongkai- } \\
\text { bi'mako }\end{array}$ & $\begin{array}{l}\text { Karena kita semua tidak ada } \\
\text { berbeda }\end{array}$ \\
\hline Ing kon tayowon in Tuhan & Apabila di hadapan Tuhan \\
\hline $\begin{array}{l}\text { Bo bayongan naton In mugutat bi } \\
\text { mototuadi' }\end{array}$ & $\begin{array}{l}\text { Dan Kita semua adalah Sanak dan } \\
\text { Bersaudara }\end{array}$ \\
\hline Yo Mototompiaan Bo Mototabiaan & Ayo Saling memberi yang baik, \\
\hline Mototanoban Ing Kita komintan & $\begin{array}{l}\text { Saling mengasihi, Saling } \\
\text { Mengingatkan kita Sekalian }\end{array}$ \\
\hline
\end{tabular}

Sumber: Wawancara Sumitro Tegela, 21 Februari 2020 lihat juga Estefien Katuuk

Lirik yang terkandung dalam lagu Mogutat Motoluadi' ingin menyampaikan pesan tentang ajakan untuk membangun hubungan persaudaraan antara satu dengan yang lain. Tanpa memandang usia (Koli gaidoing kita mogutad and moguhang Mopolinbatu inggina tobatu cim pikiran A mapoyosingong a mopoyotantan) ataupun agama (Yo napakaingkita noposikon agama). Ada pesan yang tersamarkan dalam ajakan saling bersaudara pada lirik lagu ini. Hal ini dikarenakan lirik lagu tersebut menysaratkan persaudaraan tanpa memandang agama ataupun usia. Lirik lagu tersebut tidak mencantumkan ajakan bersaudara 
tanpa memandang kesukuan maupun ras. Meskipun demikian, tetap saja lagu tersebut tidak menafikkan persaudaraan tanpa memandang rasa tau kesukuan. Hanya saja pesannya tidak tercantum dalam lirik lagu tersebut. Riffaterre (1984) dalam teori semiotiknya mengistilahkan itu sebagai matrix yang bermakna konsep abstrak yang tidak pernah teraktualisasi dan tidak muncul dalam teks tetapi pesan yang ingin disampaikan teresampaikan secara tersirat. ${ }^{40}$

Untuk membuktikan bahwa pesan tersebuat ada meskipun tidak tercantum secara eksplisit, perlu ada lirik lain yang mendukung dan menguatkan bahwa pesan persaudaraan tanpa memandang ras dan kesukuan benar-benar ada. lirik yang mendukung adanya pesan tersebut adalah Sing kita komintan in notongkaibi'mako Ing kon tayowon in Tuhan (Karena kita semua tidak ada berbeda Apabila di hadapan Tuhan). Dalam lirik ini dijelaskan bahwa di hadapan tuhan semua adalah sama. Lirik ini menunjukkan keumuman dan bisa dimaknai bahwa semua orang sama di mata tuhan tanpa memandang agama, usia, maupun suku dan ras. Inilah yang menyebabkan penciptaan makna baru (creating of meaning) yang menunjukkan bahwa lagu ini juga mengajak bersaudara tanpa memandang ras dan kesukuan.

\section{Tabel 3.}

Lagu Daerah Mongondow

\begin{tabular}{|c|c|}
\hline Transliterasi & Terjemahan \\
\hline Aka Kuma & Jika Seandainya \\
\hline Aka kuma akuoi bo na'lagapan, & Seandainya akulah seekor burung, \\
\hline Yo lumayug kumanrakarang, & Aku (akan) terbang melayang-layang, \\
\hline Momantow muik muntag kon & Meninjau semua kampung dan \\
\hline tota-buan, & ha \\
\hline Monompia kon nogutunan, & Kan membangun tempat kediaman \\
\hline Bo kayuon in dika talunon, & Dan hutan pun janganlah ditebas, \\
\hline Poniungan in bobiagon, & Perlindungan semua margasatwa, \\
\hline Ilibuin bulud bo tangaton & Di lingkungan gunung dan rimba \\
\hline Tompiaan simba' moromon, & raya, \\
\hline $\begin{array}{l}\text { Uluain tubig dika inginon, } \\
\text { Bo dikabi' monurub kon ka }\end{array}$ & $\begin{array}{l}\text { Lestarikan agar tumbuh rimbun, } \\
\text { Dan hulu sungai iangan digundulkan }\end{array}$ \\
\hline Bo dikabi monurub kon ka & Dan hulu sungai jangan digundulkan \\
\hline
\end{tabular}

${ }^{40}$ Riffaterre, Semiotics of Poetry, 1. 


\begin{tabular}{ll}
\hline \hline \multicolumn{1}{c}{ Transliterasi } & \multicolumn{1}{c}{ Terjemahan } \\
\hline Tuai mobali' pogompuon, & Dan jangan bakar hutan \\
Bo pakeonbi' taontaongon, & sembarangan, \\
Petayakan I adi' bo ompu naton, & Akan menjadi milik semua, \\
Tonggolupu' in lanoion, & Akan dipakai bertahun-tahun \\
Poyoyo singong in tompakaton & Sumber nafkah bagi anak cucu kita \\
Pototolu adi' in rigonon & Kerukunan selalu dijalankan, \\
& Menyepakati permusyarawatan, \\
& Kekeluargaan dikukuhkan. \\
\hline \hline
\end{tabular}

Sumber: Wawancara Sumitro Tegela, 21 Februari 2020

Lagu ini diawali dengan lirik yang secara eksplisit menunjukkan sebuah kiasan. Lirik tersebut berbunyi Aka kuma akuoi bo na'lagapan, Yo lumayug kumanrakarang, Momantow muik muntag kon totabuan, Monompia kon nogutunan, (Seandainya akulah seekor burung, Aku (akan) terbang melayang-layang, Meninjau semua kampung dan halamanku, Kan membangun tempat kediaman). Pencipta lagu mengandaikan jika dirinya menjadi seekor burung seekor burung, maka dia akan mengunjungi kampung halamannya. Lirik ini perlu dimaknai secara semiotic karena terjadi penggantian arti (displeacing of meaning) berupa perbedaan antara nilai yang terkandung dengan teks yang tertulis pada lirik.

Jika dilakukan pembacaan secara hermeneutik, lirik tersebut menggambarkan kerinduan seseorang kepada kampung halamannya. Tetapi karena keterbatasan, dia tidak dapat berkun-jung sehingga dia mengandaikan dirinya sebagai seekor burung agar bisa mengunjungi kampung halaman yang dirindikannya. Lirik lagu ini juga mempunyai hidden value yang menunjukkan bahwa orang-orang Mongondow sangat mencintai kampung halamannya. Kecintaan tersbut diekspresikan melalui pesan-pesan yang tertulis secara eksplisit pada penggalan lirik-lirik selanjutnya. Pesan-pesan agar menjaga alam kampung halamannya dari kerusakan-kerusakan alam yang disebabkan oleh ulah tangan manusia. Lagu ini diakhiri dengan lirik yang menyiratkan pesan untuk menjaga kekeluargaan dan mengedepankan musyarah. Ini termaktub dalam lirik Tonggolupu' in lanoion (kerukunan selalu dijalankan), Poyoyo singong in tompakaton (menyepakati permu- 
syawaratan) dan Pototolu adi' in rigonon (kekeluargaan dikukuhkan).

Secara sepintas tidak ada korelasi antara tiga lirik terakhir dengan lirik-lirik sebelumnya. Lirik sebelumnya membahas tentang pentingnya menjaga alam dari kerusakan sedangkan tiga lirik terakhir membahas tentang pentingnya musyawarah dan kekeluargaan. Akan tetapi jika dipahami secara hermeneutik seluruh lirik yang ada dalam lagu tersebut mempunyai keterkaitan. Pesan utama yang ingin disampaikan adalah agar supaya masyarakat bisa merawat alam agar tidak terjadi kerusakan. Kemudian pengelolaan alam tersebut dilakukan secara kekeluargaan yang dilandasi semangat bermusyawarah. Tujuannya agar tidak terjadi perselisihan antarmasyarakat dalam proses pengelolaan alam. Secara semiotik, lirik-lirik tentang penjagaan alam menjadi hipogram aktual yang kemudian memunculkan lirik-lirik tentang semangat musyawarah dan kekeluargaan. Dua semangat itulah yang sangat strategis dikembangkan sebagai jalan membangun toleransi dan moderasi di kalangan umat beragama yang berbeda.

\section{Tabel 4.}

Lagu Daerah Mongondow

\begin{tabular}{|c|c|}
\hline Transliterasi & Terjemahan \\
\hline Tano-Tanobon & Camkan di Hati \\
\hline $\begin{array}{l}\text { Tano-tanobon anu, in tonggina ina- } \\
\text { 'bo ana' }\end{array}$ & $\begin{array}{l}\text { Ingat dan camkan sayang, akan } \\
\text { nasehat ayah dan ibu }\end{array}$ \\
\hline $\begin{array}{l}\text { Simba' mononoi anu, ing kobobi } \\
\text { agmu }\end{array}$ & $\begin{array}{l}\text { Agar bahagia sayang sejahtera } \\
\text { hidupmu }\end{array}$ \\
\hline $\begin{array}{l}\text { Umpakabi' toruan anu, mondapat- } \\
\text { kon kotapikan }\end{array}$ & $\begin{array}{l}\text { Walaupun dimarahi sayang, } \\
\text { bahkan mendapat hukuman }\end{array}$ \\
\hline $\begin{array}{l}\text { Di kabi sintontoian anu sin mobo- } \\
\text { goibi' indalan bulawan }\end{array}$ & $\begin{array}{l}\text { Jangan berkecil hati sayang, } \\
\text { karena memberikan jalan } \\
\text { kebaikan }\end{array}$ \\
\hline $\begin{array}{l}\text { Singog tonggina indongogan, dalam } \\
\text { motulid in tutuyen }\end{array}$ & $\begin{array}{l}\text { Kata nasehat dipatuhi, jalan } \\
\text { yang lurus dituruti }\end{array}$ \\
\hline $\begin{array}{l}\text { Pia ing kamang anu, monanang ing } \\
\text { kobiagan }\end{array}$ & $\begin{array}{l}\text { Berbahagialah sayang sepanjang } \\
\text { jalanmu }\end{array}$ \\
\hline $\begin{array}{l}\text { Tagu kong gina anu, simbe mopiaing } \\
\text { kabayan }\end{array}$ & $\begin{array}{l}\text { Camkan di hati sayang, kau } \\
\text { mendapat kesejahteraan }\end{array}$ \\
\hline
\end{tabular}

Sumber: Wawancara Sumitro Tegela, 21 Februari 2020 
Dalam karya sastra terdapat teori mimetik yang menjelaskan bahwa pembuatan karya sastra didasari oleh kejadian yang dialami dalam dunia nyata. Kejadian inilah yang kemudian dipoles dengan kreatifitas dan imajinasi pengarang sehingga menjadikan karya sastra tersebut lebih hidup. Melalui pendekatan ini terlihat bahwa lagu daerah Mongondow pada Tabel 4. dibuat berdasarkan pengalaman para warga Mongondow terkait pentingnya menanamkan dalam hati makna dari lagu daerah tersebut, seabagaimana judul lagu tersebut yaitu Tano-Tanobon (Camkan di hati). Meskipun maknanya terkesan merupakan nasehat umum dari ayah dan ibu kepada anak-anaknya, namun nasehat ini dibalut dalam diksi khas daerah Mongondow yang sangat lembut sehingga akan lebih mudah diingat oleh para pendengarnya. Bobahasaan ini adalah keluwesan komunikasi yang telah menjadi ciri khas orang Sulawesi Utara di mana karakteristik berbahasa orang Melayu Manado dengan aksennya yang sangat khas, terkesan talaktif namun komunikatif dan bikin akrab. Logat dan aksen yang khas itu memang pada pandangan pertama terkesan cukup 'keras', namun hal itu sesungguhnya menunjukkan bahwa keluwesan berbahasa dalam konteks Melayu Manado adalah pintu utama dalam mengakrabkan diri. Sehingga segala sesuatu dapat dengan mudah diselesaikan jika terasa akrab.

Lagu ini menunjukkan bahwa kebahagiaan hidup, acapkali berbanding lurus dengan jalan kebaikan, terutama jika dilakukan dengan penuh kebahagiaan. Korelasinya dengan Bahasa menjadi signifikan, terutama jika dikaitkan dengan aspek kasih sayang dan kecenderungan untuk senantiasa berada dalam konstruksi moderat. Salah satu lagu daerah Mongondow tersebut menekankan pentingnya setiap anak mematuhi nasehat dari orang tua. Meskipun nasehat tersebut tidak selalu sejalan dengan keinginan anak, namun tujuannya bermuara pada kebaikan anak tersebut. Jika dimaknai secara hermeneutik, lagu ini memiliki makna yang lebih dalam. Terjadi proses creating of meaning sehingga bukan hanya dalam konteks orang tua dan anak, melainkan konteks yang lebih luas dalam kehidupan bermasyarakat. Orang tua bukan hanya ayah dan ibu kandung, namun mencakup orangorang yang 'dituakan' dalam masyarakat. Nasehat-nasehat 
mereka penting untuk terus ditanamkan dalam hati. Meskipun terdapat hukuman baik tertulis maupun tidak yang mengatur segala tingkah laku agar sejalan dengan nasehat tersebut, setiap pihak harus tetap mematuhi dan menjalankannya demi kesejahteraan bersama.

Tabel 5.

Lagu Daerah Mongondow

\begin{tabular}{ll}
\hline \hline \multicolumn{1}{c}{ Transliterasi } & \multicolumn{1}{c}{ Terjemahan } \\
\hline Mototompiaan & Tolong Menolong \\
Aka mobiag tumonggolipu Yo Moto- & Bila hidup di dalam pergaulan \\
tompiaan & Saling memberi pedoman \\
Aka mobiag tumonggolipu' Yo Moto- & Semua orang menjadi kawan \\
tompiaan & Saling berkasihan \\
Mayo Bayat im bayangala intau, & Patuhi Nasihat yang diberikan \\
Bo Mototabian & Petunjuk dijalankan \\
Tuain topotundu ta duduyan, & Bahu membahu bergandeng \\
Tongginak mogonguyang & tangan \\
Yo tumompiebi' kon dodia, & Dan saling mengenang \\
Bo Mototanoban & \\
\hline \hline
\end{tabular}

Sumber: Wawancara Sumitro Tegela, 21 Februari 2020

Lagu daerah Mongondow pada Tabel 5. menggambarkan nilai Mototompiaan (tolong menolong) yang mengakar pada masyarakat Mongondow. Lagu ini mengajak pada seluruh masyarakat agar dalam menjalani hidup tetap menjunjung tinggi rasa tolong menolong yakni saling memberikan pedoman atau petunjuk kepada siapa saja yang membutuhkan. Melalui pendekatan mimetik, terlihat bahwa karya sastra ini merupakan wujud dari harapan seluruh masyarakat Mongondow agar setiap warganya dapat menerapkan konsep tolong menolong secara menyeluruh. Penggalan lirik Mayo Bayat im bayangala intau yang berarti semua menjadi kawan menekankan bahwa tidak ada diskriminasi atas dasar apapun dalam konsep tolong menolong yang sepatutnya dipraktikkan.

Lagu ini juga mengajarkan bahwa tolong menolong tidak hanya dalam bentuk materi. Terjadi proses creating of meaning, yakni makna tolong menolong yang lebih menonjolkan rasa simpati dan pemberian nasehat atau pedoman. Bahkan tolong menolong dalam bentuk materi tidak dituliskan secara eksplisit 
dalam lagu ini agar menjadi pengingat bagi setiap pendengarnya bahwa tolong menolong dapat dilakukan dari hal yang sangat sederhana sehingga setiap orang dapat mempraktikkannya dalam kehidupan bermasyarakat. Nasihat, pedoman, ataupun petunjuk yang diberikan juga harus dilaksanakan agar tidak sekedar menjadi wacana semata.

Dalam aspek yang lebih khusus, segala bentuk sikap saling melengkapi, kesantunan, dan persaudaraan telah menjadikan masyarakat Sulawesi Utara percaya bahwa kerukunan hidup antarsesama manusia telah sedemikian tertanam dengan baik. Hal ini kemudian menumbuhkan kepercayaan diri masyarakatnya bahwa daerah yang didiami adalah daerah dengan citra rukun yang sangat tinggi, dengan sendirinya mencitrakan sikap masyarakat sehari-hari. Semakin citra rukun itu tertanam dengan baik, maka semakin jauh dari keinginan untuk saling menyakiti.

\section{Internalisasi nilai Moderasi Beragama dalam Pemaknaan atas Praktik Bahasa}

\section{Komitmen Kebangsaan}

Komitmen kebangsaan merupakan indikator dalam melihat sejauh mana pandangan, sikap dan praktik seseorang dalam beragama. ${ }^{41}$ Indikator ini kemudian menjadi ukuran dalam melihat seseorang atau kelompok seberapa moderat mereka dalam beragama dan kaitannya dengan Pancasila dan UUD1945. Dengan kata lain, seseorang menjalankan tradisi, syariat agama dan aturan masing-masing agamanya sekaligus menjalankan perannya sebagai warga negara yang taat pada tatanan kenegaraan.

Melihat konteks Orang Bolaang Mongondow yang memiliki budaya tutur yang tertuang dalam Bobahasaan, mereka pada dasarnya telah menjalankan prinsip moderasi beragama. Misalnya Bobahasaan tertuang dalam sebuah lagu daerah kemudian lagu itu dijadikan sebagai acuan dalam bersikap karena memiliki makna tertentu. Misalnya lagu daerah yang tertuang dalam tabel 1 diatas. Potongan liriknya berbunyi Tumolutuikan dodudui, Kontopotundu' in agama, Moluko' In Bahasa, Moalus in dodia

\footnotetext{
${ }^{41}$ Kementerian Agama, Moderasi beragama., 43.
} 
(Hidup jujur dan setia jalankan ajaran agama Berbahasa lembut, bertingkah laku halus). Hal itu menganjurkan cara mereka bersikap dalam menjalankan agamanya masing-masing.

Pemaknaan dari potongan lirik lagu itu membawa pesan bahwa setiap orang harus bersikap jujur, setia, lembut berbahasa dan berperilaku. Kondisi berbahasa lembut tidak hanya dimaknai sebagai sikap mereka saja tetapi juga mempertimbangkan sikap yang sama pula. Melihat pesan yang disampaikan, Bobahasaan dalam lagu tersebut menjadi sign dalam mengidentifikasi bahwa makna yang sesungguhnya adalah saling menghargai dengan tidak berkata dan berperilaku kasar.

Selain itu, lirik lagu daerah orang Mongondow yang juga menggunakan Bobahasaan dilanjutkan dengan pesan untuk "gotong royong dan membangun kampung halaman". Aspek moderasi dengan indikator komitmen kebangsaan terbaca dengan memaknai potongan kalimat ini. Gotong royong adalah bagian dari nilai luhur Pancasila. Nilai tersebut tidak dimiliki oleh bangsa lain artinya, hanya bangsa ini yang memiliki nilai itu.

Penciptaan makna ${ }^{42}$ terjadi saat Bobahasaan dituturkan saat menyebut "membangun kampung halaman" hal itu menjadi tanda bahwa orang Bolaang Mongondow harus membangun kam-pung halaman. Dengan kata lain, prinsip pembangunan sebuah wilayah telah ditanamkan dalam sanubari Orang Bolaang Mongondow.

Apabila sikap itu terinternalisasi dalam diri setiap Orang Mongondow maka komitmen kebangsaan akan terbangun dengan mudah. Terlebih lagi apabila telah diberikan pesan bahwa seseorang harus bersikap jujur, lembut dan halus dalam menjalankan agama. Hal ini sangat berkaitan erat dengan indikator moderasi beragama yakni komitmen kebangsaan. Oleh karenanya Bobahasaan warisan kebahasaan Orang Bolaang Mongondow yang mencerminkan moderasi beragama.

\section{Toleransi dalam Moderasi Beragama}

Layaknya hubungan sebab-akibat, begitulah relasi antara moderasi dan toleransi. Moderasi berperan sebagai sebab,

\footnotetext{
${ }^{42}$ Riffaterre, Semiotics of Poetry, 2.
} 
sedangkan toleransi adalah akibat yang ditimbulkan. Dalam konteks ini, tentu saja akibatnya bermakna positif. Toleransi merupakan kata benda yang merupakan ejawantah dari suksesnya proses moderasi yang dilalui. Dengan begitu, seseorang yang berhasil mengaplikasikannya dapat disebut sebagai seseorang yang toleran, dalam hal ini merupakan sikap yang ditunjukkan sebagai internalisasi pada kehidupan sosial masyarakat Bolang Mongondow.

Pada tabel-tabel lagu daerah Mongondow yang disajikan, masing-masing mengandung nilai-nilai moderasi beragama. Toleransi tentu saja tersirat sebagai outcome yang diinginkan dari nasehat-nasehat yang tercermin pada kandungan lirik lagu-lagu tersebut.

Pada tabel 1., cita-cita toleransi ditemukan pada baris Kom bonuing kobiagan (Saling memberi kebaikan, berkasih-kasihan) Mototompiaan Bo mototabian Bo Mototanoban doman (Dan saling mengenang sahabat semua insan). Dari potongan baris ini, dapat dipahami bahwa nasehat yang disampaikan yakni untuk saling mengasihi tidak terbatas pada sekelompok orang tertentu saja. Baris makna "semua insan" merujuk kepada semua manusia tanpa terkecuali. Sehingga perbedaan agama atau apapun itu, tidak boleh dijadikan pembatas bagi masyarakat Bolaang Mongondow untuk menunjukkan bentuk kasih, saling menghormati, ataupun saling menakjubi. Bukan berarti bahwa seseorang boleh saja melewati batas yang diajarkan agamanya demi menjaga pertalian dengan pemeluk agama atau kepercayaan maupun kebudayaan lain. Seperti yang tertuang pada baris selanjutnya, Kontopotundu' in agama (setia jalankan ajaran agama). Ditutup dengan lirik terakhir yakni Sim Bayongandon nato komintan in mogutatbi'motolu adi (Karena kita sekalian ini adalah sanak dan bersaudara). Baris ini memberi efek dalam yang tanpa tahu jelas sebab musababnya tetapi begitu saja dapat menjadi peredam konflik, penenang, dan penumbuh rasa kebersamaan yang harmonis. Proses ini tentu merupakan hal-hal yang perlu ada dalam usaha menumbuhkan moderasi beragama.

Hal serupa juga terkandung pada tabel 2., dengan judul Mogutat Motoluadi' (saling bersaudara). Hal ini mengajak masyarakat Bolaang Mongondow untuk merasakan bahwa setiap 
individu berpegang pada suasana batin yang saling terikat. Yo napakaingkita noposikon agama (walaupun kita beda agama, bertingkahlah yang baik), begitu seterusnya nasehat yang disampaikan membawa pesan untuk berperangai luhur terhadap sesama manusia walaupun berbeda agama. Menjauhi sifat dengki dan benci sebab kita adalah sama lalu ditutup dengan lirik yang serupa dengan tabel 1. yakni "kita semua adalah sanak dan bersaudara". Demikian terulang pada lagu lainnya yang menunjukkan bahwa sangat penting bagi tiap mereka untuk membangun pola pikir yang mendukung terciptanya moderasi beragama. Seolah menjadi pengingat yang terus digaungkan pada sejumlah lagu, Ing Kita komintan (saling mengingatkan kita sekalian), memberi kesan bahwa pencipta lagu menyadari betapa pentingnya toleransi tercipta, sekaligus sadar pula akan bahaya yang akan timbul apabila tidak demikian adanya.

Kemudian pada tabel 3., pencipta lagu menggunakan " $\mathrm{Bu}-$ rung" sebagai analogi seorang pembaharu (seandainya dia bisa) yang termaktub pada judul lagu tersebut, "Jika seandainya". Tentang bagaimana jalan yang diinginkannya, yakni seseorang yang ingin bisa "terbang melayang-layang", yang artinya mengacu pada hasrat menjaga kerukunan, kekeluargaan, dan perlindungan bagi semua. Dalam potongan lirik yang bermakna "perlindungan semua margasatwa", kata "margasatwa" merupakan representasi dari masyarakat Bolaang Mongondow dengan ragam agama, kepercayaan, dan budaya. Keinginan dan cita-cita luhur ini seolah mengajak masyarakat untuk Bersama-sama saling jaga, saling mengasihi, saling bahu-membahu. Dengan begitu, suasana damai, kerelaan untuk bermufakat, yang akhirnya menuju pada suasana kekeluargaan yang harmonis dan toleran dapat senantiasa terwujud. Hal ini dapat dilihat dari 3 baris terakhir lirik lagu tersebut.

Begitupun pada tabel 5., ajakan menuju terwujudnya toleransi didasari oleh salah satunya sikap tolong menolong (mototampiaan). Anjuran untuk saling mengingatkan dalam kebaikan, saling berbelas kasih (Bo Mototabian), serta perasaan saling mengenang (Bo Mototanoban) adalah bagian penting dari menciptakan iklim kebersamaan (Yo tumompiebi' kon dodia) dan 
harmoni masyarakat demi terwujudnya toleransi sebagai hasil dari jalan hidup moderasi.

\section{Anti Kekerasan}

Jika dilihat dalam bingkai moderasi beragama, khususnya dalam aspek anti kekerasan, lagu-lagu daerah Mongondow dapat menjadi media dalam mengampanyekan nilai tersebut. Pada lagu daerah Nonomon Kon Dodob (camkan dalam hati), terdapat lirik Kom bonuing kobiagan yang artinya saling memberi kebaikan, berkasih-kasihan. Kalimat ini mengajarkan setiap pendengarnya untuk saling mengasihi, penuh dengan kasih sayang. Lirik lainnya yaitu Mosamben tumpala intau (dan dengarkan juga semua nasihat orang tua) juga mengajarkan masyarakat Mongondow pentingnya mendengarkan nasihat orang tua. Proses creating of meaning dalam lagu ini melahirkan makna lebih mendalam bahwa dalam menghadapi suatu permasalahan dalam masyarakat khususnya dalam kehidupan beragama, maka hal yang perlu dilakukan untuk menyelesaikan masalah tersebut ialah mendengarkan nasihat orang-orang yang 'dituakan' dalam masyarakat. Bukan dengan solusi yang berujung pada kekerasan.

Pada lagu daerah lainnya yaitu Mogutat Motoluadi' (Saling Bersaudara), anti kekerasan menjadi landasan dalam setiap liriknya. Mopolinbatu inggina tobatu cim pikiran (membulatkan hati serta menyatukan pikiran), A mapoyosingong a mopoyotantan (akan membicarakan dan mempertimbangkan), yo napakaingkita noposikon agama (walaupun kita beda agama, bertingkalah yang baik), mobiag tumonpia moalus in dodia (dan halus pembawaan, berbahasa yang lembut), moluko im Bahasa kon tumpala intau (kepada sesama manusia yang hidup di dunia). Lirik-lirik tersebut secara eksplisit mengajak setiap pendengarnya untuk bertindak dengan bijaksana dan berbahasa yang lembut meskipun pada orang yang memiliki agama yang berbeda sebab setiap manusia adalah saudara. Hal ini merupakan poin utama dalam konsep anti kekerasan yang termuat dalam moderasi beragama. Segala perbedaan yang tak dapat dihindari dalam kehidupan beragama bukanlah menjadi alasan untuk membenarkan kekerasan. Membicarakan dan mempertimbangkan adalah langkah awal yang perlu ditempuh untuk mencapai solusi terbaik. Bahkan lagu ini mengingatkan kita untuk menjaga tindak 
tutur, khususnya pada orang yang berbeda agama. Hal ini dapat mewujudkan tercapainya masyarakat yang moderat.

Nilai anti kekerasan juga termuat dalam lirik lagu daerah Aka Kuma (Jika Seandainya). Secara heuristik, lagu ini memiliki arti perlindungan margasatwa. Namun, jika dimaknai secara secara hermeneutik, lagu ini memiliki makna yang mendalam. Bo kayuon in dika talunon (dan hutan pun janganlah ditebas), poniungan in bobiagon (perlindungan semua margasatwa), uluain tubig dika inginon (dan hulu sungai jangan digundulkan), bo dikabi' monurub kon kayuon (dan jangan bakar hutan sembarangan). Penggalan lirik ini menjelaskan perlindungan margasatwa, sungai, dan hutan. Dalam karya sastra ini terjadi pergantian makna (displacing of meaning) yakni terjadi penggunaan bahasa kiasan atau metafora. Hal ini terlihat pada lirik akhir lagu tersebut yaitu tonggolupu' in lanoion (kerukunan selalu dijalankan), poyoyo singong in tompakaton (menyepakati permusyarawatan), pototolu adi' in rigonon (kekeluargaan dikukuhkan). Dari judul dan lirik lagu ini dapat disimpulkan bahwa pengarang lagu menganalogikan dirinya seperti seekor burung yakni margasatwa yang butuh perlindungan.

Kesatuan lirik lagu ini menjelaskan bahwa penggunaan kata sungai dan hutan sebagai habitat seekor burung merupakan metafora. Kata-kata ini pada makna yang sebenarnya adalah bukan hanya seekor burung, melainkan makhluk hidup dan tempat hidupnya. Dalam kehidupan bermasyarakat, khususnya dalam aspek beragama, lagu ini mengandung nasihat untuk melindungi seluruh manusia dan tempat tinggalnya. Peng-gundulan hulu sungai dan pembakaran hutan merupakan bentuk kekerasan yang mengancam keberlangsungan hidup. Demikian pula dalam bermasyarakat khususnya dalam beragama, lagu ini tidak membenarkan perilaku kekerasan yang dapat membahayakan manusia terutama yang memiliki agama yang berbeda. Kerukunan, musyawarah, dan kekeluargaan merupakan nilai-nilai yang diangkat dalam lagu ini sebagai jalan anti kekerasan.

Pada lagu daerah Tano-tanobon terdapat lirik Umpakabi' toruan anu, mondapatkon kotapikan yang artinya Walaupun dimarahi sayang, bahkan mendapat hukuman. Sepintas lirik ini mengandung kekerasan sebab menggunakan kata hukuman. Hal 
ini dapat memicu pada proses penyimpangan makna (distorsing of meaning) sebab terdapat kata hukuman yang bermakna ambigu. Namun, jika dimaknai secara luas, hukuman bukanlah sebuah kekerasan melainkan perlakuan yang diberikan agar seseorang memahami konsekuensi dari perbuatannya yang melanggar aturan. Lebih lanjut, terjadi proses penciptaan makna (creating of meaning) yakni hukuman yang diberikan bukanlah dalam bentuk kekerasan sebab hukuman ini ditujukan untuk kebaikan sebagaimana termuat dalam lirik di kabi sintontoian anu sin mobogoibi' indalan bulawan (jangan berkecil hati sayang, karena memberikan jalan kebaikan). Sehingga dapat dimaknai bahwa hukuman yang diberikan berupa perlakuan anti kekerasan yang bertujuan memberikan manfaat kepada pelakunya.

Lagu ini menekankan bahwa hukuman diperlukan dalam menjalani kehidupan bermasyarakat agar dapat berjalan tertib. Hal ini pun sesuai dengan konsep moderasi beragama, yakni tidak memberikan kebebasan sepenuhnya pada masyarakat. Aturan tetap berlaku agar masyarakat dapat adil dan berimbang dalam menjalankan praktik beragama di masyarakat. Namun yang menjadi perhatian penting ialah jenis hukuman yang diberikan tidak mengandung unsur kekerasan (anti kekerasan).

Lagu lainnya ialah Matotompiaan (tolong menolong), terdapat beberapa lirik yang sangat relevan dengan konsep antikekerasan dalam modetasi beragama. Aka mobiag tumonggolipu' Yo Mototompiaan (saling memberi pedoman), Mayo Bayat im bayangala intau (semua orang menjadi kawan), Bo Mototabian (saling berkasihan) merupakan lirik yang mengajak pendengar untuk mempraktikkan sikap anti kekerasan dalam kehidupan bermasyarakat. Saling memberi nasihat dan saling menyayangi terhadap semua orang, tanpa memandang agama yang dianutnya juga tidak lepas dari ide anti kekerasan dalam moderasi beragama.

\section{Akomodatif Terhadap Budaya Lokal}

Pada lirik lagu berjudul Nonomon Kon Dodob mengandung beberapa pesan bijak untuk menjalani kehidupan sehari-hari. Salah satu di antaranya adalah ajakan untuk saling bergotong royong antara satu dengan lainnya. Ajakan bergotong royong 
tersebut tertuang dalam lirik Tonggolipu in dika koliongan, Bo pogugutat in pobaya'an, Monompia kon Totabuan, Tagu'an kon adi' boampu yang artinya gotong royong janganlah dilupakan dan membangun kampong halaman warisan anak cucu kita. Secara leksikal, lirik tersebut mengandung pesan untuk bergotong royong membangun kampung halaman yang diperuntukkan bagi anak cucu keturunannya dikemudian hari. Hal ini dilakukan karena orang mongondow merupakan sanak dan saudara satu dengan yang lainnya.

Lirik lagu Nonomon Kon Dodoh tidak hanya teks normatif yang hanya cukup dibaca saja. Lagu ini merupakan karya sastra yang di dalamnya mempunyai beberapa makna dibalik kata-kata yang Nampak secara jelas. Untuk memahaminya diperlukan pemaknaan yang melibatkan pemikiran dan interpretasi pendengar maupun penyanyinya. Riffaterre berasumsi bahwa karya sastra merupakan perwujudan sebuah ide yang dipaparkan dengan cara yang berlainan dengan mempertimbangan unsur estetika. Hal tersebut bisa terjadi oleh beberapa faktor seperti pergantian arti (displacing of meaning), penyimpangan arti (distorting of meaning), dan penciptaan arti (creating of meaning). Agar bisa memahami dinamika pemaknaan yang terjadi dalam sebuah karya sastra Riffaterre menawarkan metode pembacaan heuristik dan hermeneutik ${ }^{43}$.

Pembacaan heuristik merupakan sistem semiotik tingkat pertama berupa teknik pembacaan berdasarkan struktur kebahasaan. Sedangkan pembacaan hermeneutik merupakan sistem semiotik tangkat dua yakni pembacaan ulang sesudah pembacaan heuristik dengan memberikan konvensi sastranya. Paparan di atas tentang makna lirik Tonggolipu in dika koliongan, Bo pogugutat in pobaya'an, Monompia kon Totabuan, Tagu'an kon adi' boampu menggunakan metode pembacaan heuristik yang bermkana gotong royong untuk membangun kampung halaman yang diperuntukkan bagi anak cucu. Selanjutnya, apabila lirik tersebut dibaca menggunakan pembacaan hermeneutik maka

${ }^{43}$ Siti Fatimah Fajrin, "SEMIOTIKA MICHAEL CAMILLE RIFFATERRE Studi Analisis Alquran Dalam Surat Al-Baqarah Ayat 223," Jurnal Iти Al Quran dan Tafsir, vol. 2, 2019. 
akan di dapat makna bahwa lirik tersebut adalah kiasan. Makna sebenarnya tidak hanya gotong royong membangun kampung halaman melainkan mempunyai makna yang lebih luas yakni bergotong royong dalam berbagai aspek kehidupan untuk saling tolong menolong satu dengan lainnya.

Bahkan jika ditelaah lebih dalam lirik tersebut juga mengajak untuk merawat tradisi milik orang mongondow yang telah turun temurun diwariskan dari generasi ke genearasi. Pada lirik tersebut frasa gotong royong diwakili oleh istilah pogugutat. Adapun pogugutat itu sendiri merupakan sebuah tradisi turun temurun orang-orang Mongondow. Tradisi Pogugutat merupakan kerjasama masyarakat dalam bentuk bentuk interaksi sosial yang terstruktur dalam mengatasi permasalahan pemenuhan kebutuhan dalam merealisasikan hajatan masyarakat tanpa memandang, suku, ras, dan agama ${ }^{44}$.

Ajakan merawat tradisi inilah yang kemudian berkolerasi dengan semangat moderasi beragama. Dalam modul moderasi beragama yang diterbitkan oleh Kementrian Agama dijelaskan bahwa salah satu indikator moderasi beragama adalah akomodatif terhadap budaya lokal dan tradisi. Orang-orang moderat condong memiliki keramahan alam menerima tradisi dan budaya local dalam perilaku keagamaannya, sejauh tidak bertentangan dengan pokok ajaran agama.

Setelah melewati proses pembacaan hermeneutik, lirik lagu Nonomon Kon Dodoh pada part Tonggolipu in dika koliongan, Bo pogugutat in pobaya'an, Monompia kon Totabuan, Tagu'an kon adi' boampu sebenarnya mengandung pesan moderasi beragama. Pesan dalam lirik ini ingin menyampaikan bahwa meskipun orang-orang mongondow hidup dalam keragaman beragama, mereka harus tetap mengakomodasi tradisi-tradisi luhur yang telah diwariskan oleh ornag-orang tua terdahulu salah satu di antaranya adalah tradisi pogugutat. Tanpa perlu mempertentangkan nilai-nilai yang terdapat pada tradisi lokal dengan nilai-nilai agama. Karena keduanya mengarahkan pada kebaikan.

${ }^{44}$ Muhibbuddin Muhibbuddin, "Persentuhan Filantropi Islam dan Budaya Lokal," Al-Buhuts, 2019, https://doi.org/10.30603/ab.v15i1.947. 


\section{PENUTUP}

Praktik kebahasaan Masyarakat Bolaang Mongondow memiliki fungsi sebagai wadah penyampaian pesan moderasi beragama. Bobahasaan merupakan wujud dari moderasi beragama orang Mongondow. Bobahasaan kemudian tertuang dalam lagu daerah dengan berbagai pesan leluhur. Tingkat bahasa yang digunakan cukup sastrawi dan lembut oleh karenanya dibutuhkan pendekatan semiotika untuk membaca tanda yang disampaikan oleh Bobahasaan itu sendiri.

Semiotika Michael Camille Riffaterre digunakan untuk melihat makna dari Bobahasaan yang tertuang dalam lagu daerah orang Bolaang Mongondow. Dengan melihat makna teks melalui sudut pandang semiotik maka aspek moderasi dari Bobahasaan dapat ditarik sehingga Bobahasaan menjadi wadah menghidupkan moderasi. Moderasi beragama akhirnya hidup dalam masyarakat dalam bentuk Bobahasaan yang tertuang dalam lagu daerah.

Internalisasi moderasi beragama akhirnya tampak dari proses pemaknaan Bobahasaan. Proses pemaknaan juga terkait dengan data tekstual yang ditemukan. Data tersebut juga memiliki hubungan antar teks yang menggambarkan pesan leluhur. Hubungan antar teks itu kemudian melahirkan pemaknaan holistik yakni Bobahasaan merupakan wujud moderasi beragama dari Orang Bolang Mongondow.

\section{DAFTAR PUSTAKA}

\section{Buku}

Abdullah, Irwan. Agama dan Kearifan Lokal dalam Tantangan Global. Yogyakarta: Sekolah Pascasarjana UGM dan Pustaka Pelajar, 2008.

As'ad, Muhammad. Agama dalam Dimensi Sosial dan Budaya (Studi Tentang Upacara Siklus Hidup Masyarakat Bolaang Mongondow). Makassar: Balai Penelitian Lektur Keagama- 
an Ujungpandang, 1998.

Asdi, Dipodjojo. Folklore dan Pendidikan: Dalam Publikasi Ilmu Keguruan Sastra Seni. 1 ed. Yogyakarta: FKSS IKIP, 1970.

Balai Pelestarian Nilai Budaya (BPNB) Manado. Upacara Monibi di Bolaang Mongondow. Yogyakarta: Kepel Press, 2015.

Beatty, Andrew. Varieties of Javanese Religion: An Anthropological Account. Cambridge: Cambridge University Press, 2004.

Cresswell, Jhon W. Research Design, Qualitative and Quantitative Approaches. California: Thousand Oaks, 1994.

Finnegan, Ruth. Oral Traditions and The Verbal Arts: A Guide to Research Practices. London: Routledge, 1997.

Geertz, Clifford. "Religion as Cultural System” Local Knowledge: Futher Essays in Interprtative Anthropology. New York: Basic Book, 1983.

Goode, Wiliam J. Sosiologi keluarga. Jakarta: Bumi Aksara, 1995.

Hasanuddin. Kerajaan Bolango: Dari Tapa Ke Bolaang Uki (Suatu Tinjauan Sejarah Sosial). Yogyakarta: Amara Books., 2013.

Kementerian Agama. Moderasi beragama. Badan Litbang dan Diklat, Departemen Agama RI, 2019.

Milles, M.B. and Huberman, MA. Qualitative Data Analysis. London: Sage Publication. London: Sage Publication, 1994.

Muslim, Abu, Muhammad Sadli Mustafa, Muhammad Subair, dan Lasakka. "Merawat Kerukunan Umat Beragama Berbasis Kearifan Lokal di Kawasan Timur Indonesia." Makassar, 2016.

O’dea, Thomas F. Sosiologi Agama Suatu Pengenalan Awal 
(Terj.). Jakarta: CV. Rajawali, 1985.

Ong, Walter J. Orality and Literacy: The Technologizing of the Word Diterjemahkan Oleh Iffati, Rika. Kelisanan dan Keaksaraan. London and New York: Routledge, 2013.

Parekh, Bikhu. Rethinking Multiculturalism: Cultural Diversity and Political Theory. London: Macmilan, 2000.

Purba, Jhon Rivel. Sejarah Sosial Ekonomi Bolaang Mongondow 1901-1905. Yogyakarta: Amara Books, 2019.

Rahawarin, Yunus. "Kerjasama Antar Umat Beragama dalam Menyelesaikan Konflik di Kota Ambon dan Kota Tual Maluku." UIN Sunan Kalijaga Yogyakarta, 2012.

Riffaterre, Michael. Semiotics of Poetry. Bloomington [Ind.]:

Indiana University Press, 1984.

Ritzer, George. Sosiologi Ilmu Pengetahuan Berparadigma Ganda. Jakarta: Rajawali Press, 1992.

Rusli, Almunawar Bin. "Laporan Penelitian Folklore Bolaang Mongondow," 2020.

Sabara. "Indeks Kerukunan Umat Beragama di Kabupaten Muna." Makassar, 2014.

Saud, Lily E.N. Budaya Masyarakat Suku Bangsa Bolaang Mongondow di Sulawesi Utara. Proyek Pem. Manado: Kementerian Kebudayaan dan Pariwisata Deputi Bidang Pelestarian dan Pengembangan Budaya Balai Kajian Sejarah dan Nilai Tradisional Manado, 2004.

Sombowadile, Pitres. Kearifan Lokal Kaitannya dengan

Pembentukan Watak dan Karakter Bangsa di Bolaang Mongondow Selatan. Balai Pelestarian Nilai Budaya Manado. Yogyakarta: Kepel Press, 2012.

Sugiyono. Metode Penelitian Pendidikan dan Pendekatan Kuantitatif, Kualitatif, dan $R \& D$. Bandung: Alfabeta, 2010. Sumolang, Steven, dan Janeke Peggy. Pemetaan Konflik Sosial 
pada Masyarakat Dumoga di Kabupaten Bolaang Mongondow. Yogyakarta: Amara Books, 2018.

Zoetmulder, P.J. "“The Significance of the Study of Culture and Religion for Indonesian Historiography." In An Introduction to Indonesian Historiography, diedit oleh Soedjatmoko. Jakarta: PT Equinox Publishing Indonesia, 2007.

\section{Jurnal Ilmiah}

As'ad, Muhammad. "Agama dalam Dimensi Sosial dan Budaya Lokal: Studi tentang Upacara Siklus Hidup Masyarakat Bolaang Mongondow." Al-Qalam 10, no. 2 (2018): 55. https://doi.org/10.31969/alq.v10i2.600.

Fajrin, Siti Fatimah. "SEMIOTIKA MICHAEL CAMILLE RIFFATERRE Studi Analisis Alquran Dalam Surat AlBaqarah Ayat 223." Jurnal Imu Al Quran dan Tafsir. Vol. 2, 2019.

Fairlough, Norman, dan Ruth Wodak. "Critical Discourse Analysis." In Discourse as Social Interaction: Discourse Studies A Multidisiplinary Introduction, diedit oleh Teun A. van Dijk (ed), Vol. 2. London: Sage Publication, 1997.

Mashudi. "Pendidikan Keberagaman Sebagai Basis Kearifan Lokal (Gagasan Kerukunan Umat Beragama)." Jurnal Tarbawi 2, no. 1 (2014): 47-66.

Muhibbuddin, Muhibbuddin. "Persentuhan Filantropi Islam dan Budaya Lokal." Al-Buhuts, 2019. https://doi.org/10.30603/ab.v15i1.947.

Muslim, Abu. "Kitorang Samua Basudara: Bijak Bestari di Bilik Harmoni." Jurnal Harmoni, Puslitbang Kehidupan Keagamaan Badan Litbang dan Diklat Kementerian Agama Republik Indonesia 15, no. 2 (2016).

Muslim, Abu, Idham, dan Muhammad Subair. "Iko-Iko Siala Tangang (Tracing Moderatism of Religious Concept From 
the Oral Traditions of Bajau)." In Proceedings of the First International Conference on Religion and Education 2019, October 8-12 2019, diedit oleh Dkk Basri. Bintaro: European Union Digital Library (EAI), 2019. https:// doi.org/http://dx.doi.org/10.4108/eai.8-10-2019.2294520.

Sila, Muhammad Adlin. "Sila, Adlin. 2011. Peta Penelitian Budaya di Lingkungan Badan Litbang dan Diklat Kementerian Agama RI." Harmoni (Jurnal Multikultural dan Multireligius) X, no. 4 (2011).

\section{Media Cetak}

Ahmad, Rumadi. "Penguatan Moderasi Beragama." Kompas. 8 Juli 2019. 